\section{Use of the fine powder of ornamental industry as ceramic raw material}

FARAH SILVA - Universidade Federal de Pernambuco, PPGEMinas - faradiba@ufpe.br Felisbela OLIVEIRA - Universidade Federal de Pernambuco, PPGEMinas JúLIo SOUZA - Universidade Federal de Pernambuco, PPGEMinas

Received: 12.09.2009. - Érkezett: 2009.09.12. http://dx.doi.org/10.14382/epitoanyag-jsbcm.2010.6

In the Industrial District of Suape in Pernambuco about $120 \mathrm{~m}^{3}$ of abrasion mud is being formed every month. This viscous pulp composed of steel grains, hydrated lime, water and rock powder (about $40 \%$ of the mass of the block) is produced during cutting of rock blocks and production of plates. The abrasion mud has remarkable iron content, but it does not peril the mechanical performance of red ceramics produced from that. The waste material of rock cutting and polishing contains fine sand particles from the polishing powder. The grading curve of the clay clearly shows the presence of different size fractions. Thus, the abrasion mud can be added to the clay used for ceramic production. Samples of rock dust did not show plasticity and flow properties. The plasticity required in a mass ceramic can be provided by the use of dark clay of high plasticity. The rational use of particular waste decreases the environmental impact of rock cutting and broadens the spectrum of potential raw materials, as well.

\section{Introduction}

The production of ornamental stone in the decade of 1980 was mainly of marbles, a rock composition of carbonatics. The exploitation of "granite" was only intensified at the end of the decade. Production and manufacture of marbles and granites, which had increased between 1991 and 1994, decline between the years 1994 and 1995, due to offers imported product and the exchange rate politic of recovery of the national currency. The production of raw and manufactured marbles decreased between 1996 and 1998, but in the following year, the production has been recovering. The depreciation of the currency at the beginning of 1999 with the deployment of the floating exchange rate encouraged for such resumption.

The production of ornamental plates, in industries for beneficiary eligibility, creates waste during the process of sawdust, polimentos, among other treatments surface of the plates, the rocky blocks. In Brazil, the quantity of waste resulting therefrom the cutting of marble and granite is of the order of 240000 ton/year, distributed among the states of Espírito Santo, Bahia, Ceará and Paraíba. The residue arising from the beneficiary eligibility of ornamental rock is a pulp in some viscosity, composed of water, hydrated lime, granalha steel and powder of rock, resulting in the sawdust of blocks in rocky plates, generating large quantities of waste, estimated in about $40 \%$ of the mass of the block. These wastes are the mud abrasive. The industries of beneficiary eligibility of rock, generating waste of mud abrasive, in the state of Pernambuco are few and distributed mainly in the municipalities of Calves, Bom Jardim District and the Industrial de Suape, where there are approximately generation of $120 \mathrm{~m}^{3} /$ mês of mud abrasive.

\section{Processing ornamental}

In industrial units, the rocky trading blocks, which weigh around 30 tons and go through two types of beneficiary eligibility: the primary for obtaining mainly of plates with standard thicknesses of 10,20 or $30 \mathrm{~mm}$, through the use of looms, and secondary, with treatment of surface in plate (polishing, etc.), followed by cutting dimensions of the final product. For coating of floors or walls among other purposes, as Peyneau et. al. (2004) Fig. 1., and Souza (2005). The sawdust blocks of rocky trading in plates or plates semi-finished looms in multi blade is aided by a pulp, or mixture of granalha steel (abrasive material), hydrated lime and water, which is in a well tank below the tear, where this mud is pumped continuously up of blocks through a system of showers in motion and has been in a closed loop. This process for transforming the bloc into plates is the main responsible for the generation of large quantities of waste in the form of mud (water, hydrated lime, granalha steel and powder of rock ground). It is estimated that about 30 to $40 \%$ of the mass of the block composes the waste, according Silva et. al. (2005).

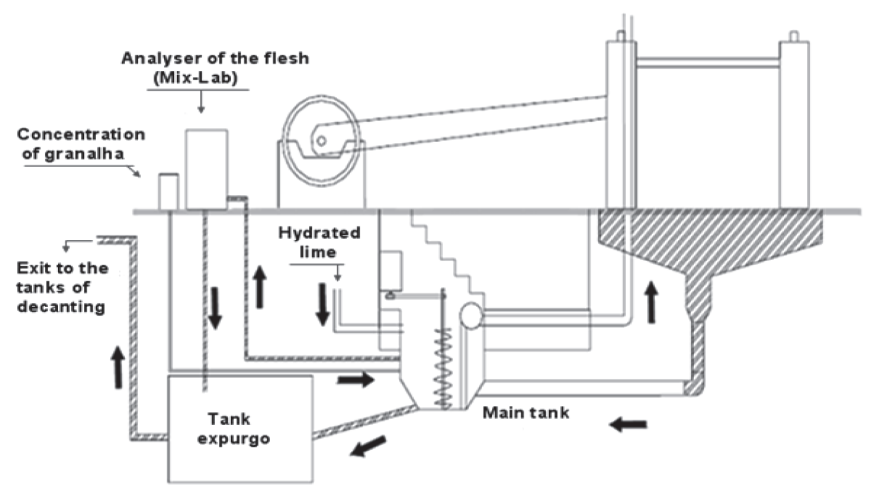

Fig. 1. Clyde of movement of the mixture

1. ábra A keverék mozgatásának ábrázolása

The mud has a viscosity control, with the addition of water and lime, and the amount of granalha is monitored to avoid compromising the quality of cutting of the plate. Cutting 
the plates is carried out through the friction of the blades against the Block, together with the abrasive mud containing the granalha steel. When the mixture is outside of the range, depending on the excess of stone dust and the wear of granalha, part of the mixture is released to another tank (tank expurgo) and new ingredients are added the mud abrasive (water, lime and granalha), to maintain the standard. The whole mixture retained the Tank expurgo is treated as the residue, which is pumped into the tank of decanting, located in the courtyard of the company until it reaches a more consistent, to then be transported by truck to an area of landfill.

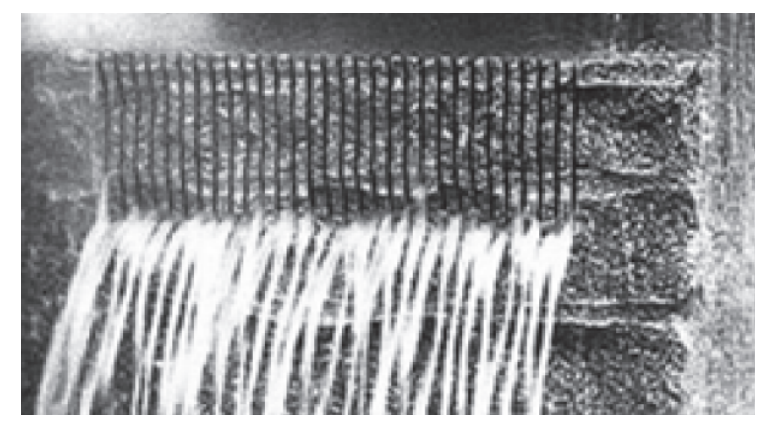

Fig. 2. Cutting the block in plates

2. ábra Kötömbök lapokra fürészelése

\section{Ceramic industries}

The use of solid residue (abrasive mud) is possible due to the nature of the rock constituent of the marbles and granites. The marble is a metamorphic rock crystal of composition calcite $\left(\mathrm{CaCO}_{3}\right)$, or composition of magnesium, called dolomito marble $\left(\mathrm{CaMg}\left(\mathrm{CO}_{3}\right)_{2}\right)$. The lime $(\mathrm{CaO})$, is a chemical element in rock predominant carbonates with a property permissible in industrial ceramics and for applications in the building industry.

The granite is composed of feldspars, micas and quartz, are minerals of macroscopic dimensions, characteristic of a rock igneous. The minerals of the rock granite are used as aggregate in accordance with the allowable size for the manufacture of ceramic products in the ceramics industry and as fine aggregate for the manufacture of mortars for use in industrial construction.

The reject produced presents its chemical elements in the form of oxides: are silica $\left(\mathrm{SiO}_{2}\right)$ and alumina $\left(\mathrm{Al}_{2} \mathrm{O}_{3}\right)$, followed by lime $(\mathrm{CaO})$ and the alkali oxides of sodium and potassium respectively $\left(\mathrm{Na}_{2} \mathrm{O}, \mathrm{K}_{2} \mathrm{O}\right)$. The levels of oxides of iron can be significant, coming mainly from the formation of mineral máficos of granites rocks. The iron can be recovered from the mud abrasive (granalha) for other purposes, through the magnetic separator of high or low intensity. The minerals (powder of stone) can be used for noble purposes: used in the ceramics industry (white and red), or as fine aggregate for the construction industry.

Waste marbles and granites are compatible with the chemical compositions and physical pre-requested the ceramics industry, for the mixed ceramics. The mud presents are compatible granulometry potential to be incorporated into mass clayey used for the manufacture of ceramic products. The application in the ceramics industry is due to its ownership of behavior, plastic, characteristic of ceramic material, as an example manufacture of bricks for structural, paving of streets and sidewalks. It is, therefore, a material of good resistance and high durability.

Some chemical elements contained in the residue of mud abrasive behavior are necessary to ceramics industry, as an example the iron oxide, when subjected to high temperatures, but this property is not necessary for the ceramic industry. Contents of iron are acceptable in the chemical composition of the traditional red ceramic used for the manufacture of tiles, bricks massive, structural blocks, blocks of sealing, elements cast, lightweight aggregates and so on. The red ceramic includes tools for domestic use as pots, sleepers and carvings include objects as vases and so on. The ceramics industry is part of the overall production chains of complex civil construction.

The Associação Brasileira de Cerâmica (ABC) admit the annual value of the order of US $\$ 6$ billion in production ceramics Brazilian, of which US\$750 million relate to the consumption of natural raw materials. Brazil occupies the fourth place as a world producer of ceramic coating after China, Italy and Spain. The structural ceramics red move around 60000000 tons of raw materials annually, with reflections on the routes of transport and the environment, exploitation of clay. The ceramic coating is a sector that has shown high performance technology, with the estimate of 121 industrial units producing tiles, floors and coating the external walls, in the amount of 400.7 million $\mathrm{m}^{2}$ in 1998 , representing $88.1 \%$ of the 455 million of $\mathrm{m}^{2}$ of installed capacity, Bustamante et. al. (2000).

\section{Materials and methods}

The materials studied in this research are waste of sawing boards for ornamental rocks and clay material used in ceramic industry. The residue from sawing of the blocks (Fig. 3. (B)) was collected in the courtyard of an enterprise from rocks. It is waste that it is often accumulated in the courtyard of the company, becoming an environmental liability without viable use. The clay was collected in the ceramic industry installed in the municipality of Paudalho, PE (Fig. 3. (A)).
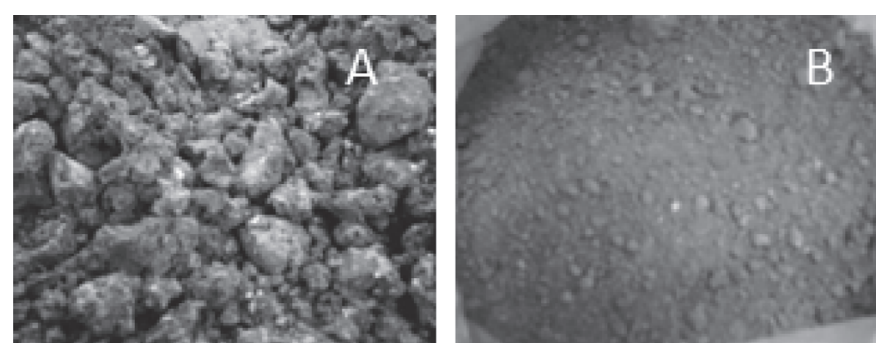

Fig. 3. (A) Clay; (B) Fine powder of sawdust

3. ábra (A) Agyag; (B) Finom fürészelési por

The mixture was evaluated from the so-called Atterberg Limits, Liquid Limit (LL) and Limit of Plasticity (LP). The method used for determination of LL was designed by Arthur Casagrande (Fig. 4.). The ABNT standardized this process through the NBR 6459, determining the limits of plasticity based on the standard NBR 7180 of ABNT. 

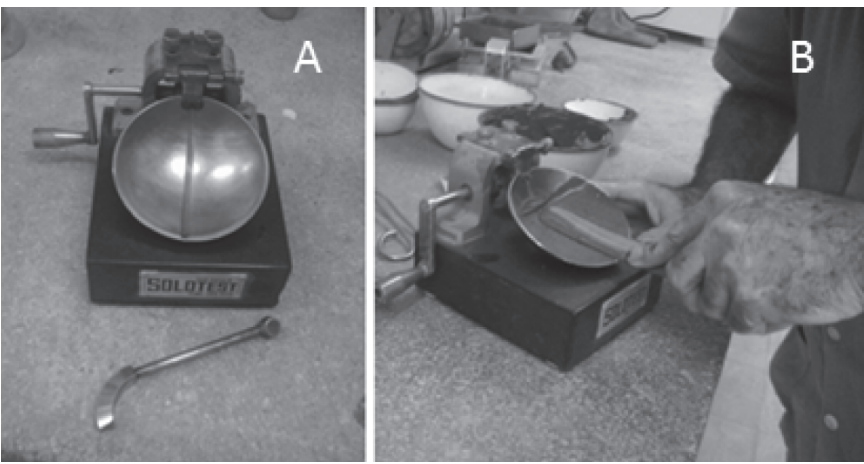

Fig. 4. Equipment standardized by Arthur Casagrande

4. ábra Az Arthur Casagrande által szabványositott berendezés

The size analysis of materials was carried out according to NBR 7181. The specific weight of grains, which corresponds to the weight of solid substance per unit volume, was determined by the method of picnometer adopted by ABNT in your MB 28 (Fig. 5.).

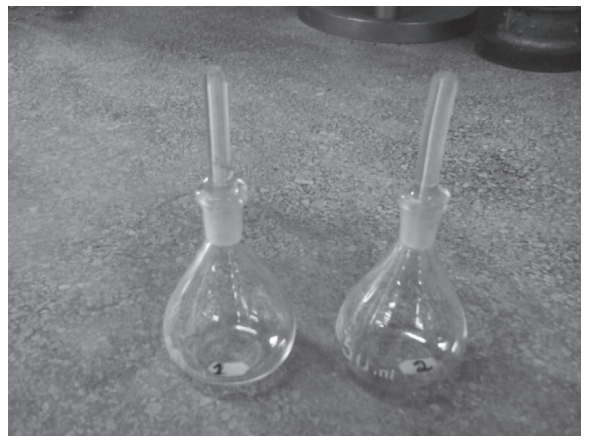

Fig. 5. Picnometer one and two

5. ábra Egyes és kettes piknométer

\section{Results and discussion}

The granulometric analyses of various materials are shown in Fig. 1., the coefficient of uniformity so that the curve of the powder particles is 17167 , indicating that this material is less uniform on the coefficients of lower values. The powder of sawdust in your size presents percentage of particles bystanders fine sand grain size (Fig. 2.). About $30 \%$ of the material shows larger than No. 200 sieve, concentrating its size that on the fine sand fraction. The grains are remnants of the granular fraction of this size, because they resist the process of sawing. This is demonstrated through observation of tactile-visual portions retained in sieves of mesh above the opening paragraph 200 (sieves 100, 50, 40, 30, 160) (Fig. 6. (A) and (B)).
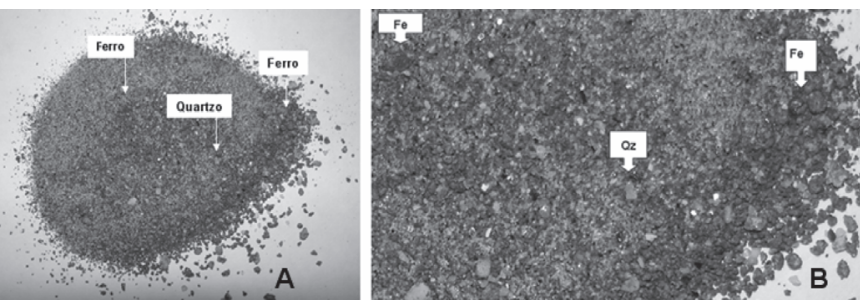

Fig. 6. (A) Powder of sawdust in sieve No. 200; (B) Iron and crystals of quartz

6. ábra (A) A fürészelési por szitamaradéka a No. 200-as szitán; (B) Vas- és kvarcszemcsék

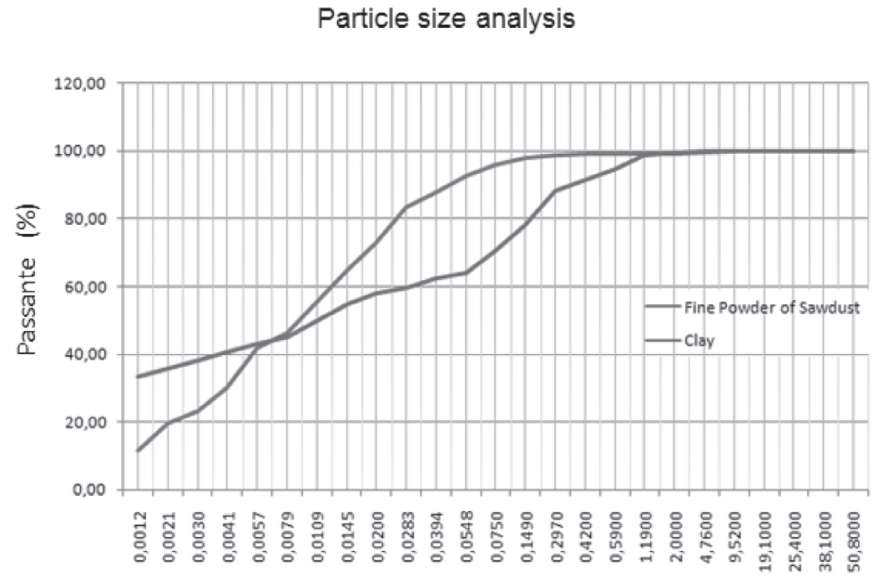

Diameter of grains $(\mathrm{mm})$

Fig. 7. Curve size of fine powder of sawdust and clay

7. ábra A finom fürészelési por és az agyag szemcseméret eloszlása

Chemical analysis of the fine powder of sawdust shows high levels of $\mathrm{Fe}_{2} \mathrm{O}_{3}, \mathrm{CaO}$ and $\mathrm{K}_{2} \mathrm{O}$. The $\mathrm{Fe}_{2} \mathrm{O}_{3}$ is admissible in red ceramic binders and $\mathrm{CaO}$ has power, and welcome to the ceramic industry. The high content of $\mathrm{K}_{2} \mathrm{O}$ is no damage because the composition ceramic $\mathrm{K}_{2} \mathrm{O}$ is the mineral-shaped crystal.

\begin{tabular}{lcc} 
Chemical elements & Clay & $\begin{array}{c}\text { Quantitative Analysis Chemical } \\
\text { Fine powder of } \\
\text { sawdust }\end{array}$ \\
$\mathrm{SiO}_{2}$ & 69.00 & 64.10 \\
\hline $\mathrm{Al}_{2} \mathrm{O}_{3}$ & 15.60 & 14.00 \\
\hline $\mathrm{K}_{2} \mathrm{O}$ & 2.21 & 5.20 \\
\hline $\mathrm{Fe}_{2} \mathrm{O}_{3} \mathrm{~T}$ & 5.56 & 9.16 \\
\hline $\mathrm{Na}_{2} \mathrm{O}$ & 3.89 & 2.43 \\
\hline $\mathrm{MgO}$ & 0.85 & 1.17 \\
\hline $\mathrm{CaO}$ & 1.45 & 3.23 \\
\hline $\mathrm{TiO}$ & 1.02 & 0.31 \\
\hline $\mathrm{P}_{2} \mathrm{O}_{5}$ & 0.04 & 0.05 \\
\hline $\mathrm{MnO}$ & 1.13 & 0.11 \\
\hline $\mathrm{Rb} O$ & 0.01 & 0.04 \\
\hline $\mathrm{SrO}$ & 0.04 & 0.04 \\
\hline $\mathrm{BaO}$ & 0.11 & 0.10 \\
\hline $\mathrm{p} . \mathrm{f}$. & 0.09 & 0.14 \\
\hline $\mathrm{Total}$ & 101.01 & 100.07 \\
\hline
\end{tabular}

Table 1. Chemical elements of the clay and dust fine cutting of ornamental 1. táblázat Az agyag és a díszitőkő-fürészelési finom por kémiai összetétele

Chemical analysis of the fine powder of sawdust shows high levels of $\mathrm{Fe}_{2} \mathrm{O}_{3}, \mathrm{CaO}$ and $\mathrm{K}_{2} \mathrm{O}$. The $\mathrm{Fe}_{2} \mathrm{O}_{3}$ is admissible in red ceramic binders and $\mathrm{CaO}$ has power, and welcome to the ceramic industry. The high content of $\mathrm{K}_{2} \mathrm{O}$ is no damage because the composition ceramic $\mathrm{K}_{2} \mathrm{O}$ is the mineral-shaped crystal.

The sample of rock dust in the process of sawing has no limits of plasticity and liquidity. Therefore, the plasticity of the required mass of pottery clay can be purchased used. The clays 
show the plasticity index (PI) equal to 24.39. According to the classification of Jenkins, the clay is highly plasticity. Plasticity ensures less damage during the extruded ceramics, capable of deformation, and is responsible for the greater strength of the ceramic piece.

\begin{tabular}{ccc}
\multicolumn{2}{c}{ Physical Characteristics of Materials } \\
Properties & Clay & $\begin{array}{c}\text { Fine powder of } \\
\text { sawdust }\end{array}$ \\
\hline Limit of plasticity (\%) & 17.620 & $\mathrm{NP}$ \\
\hline Limit of liquidity (\%) & 42.010 & $\mathrm{NL}$ \\
\hline $\begin{array}{c}\text { Average real density } \\
\left(\mathrm{g} / \mathrm{m}^{3}\right)\end{array}$ & 2.655 & 2.705 \\
\hline Average humidity (\%) & 2.740 & 0.590 \\
\hline
\end{tabular}

Table 2. Indices and physical indices of consistency, (NP) not plastic, (NL) liquid limit not determined

2. táblázat Konzisztencia indexek és fizikai mutatószámok, (NP) nem plasztikus, (NL) a folyóssági határérték nincs meghatározva

\section{Conclusion}

The waste industrial processing of ornamental stones is a potential source of raw material to be applied in the production of mortar with industrial purposes in the construction and industry of ceramics red, with low costs for beneficiary eligibility of iron contained in the waste.

The reuse of the residue (abrasive mud) will decrease the volume of raw material extracted directly on nature for the construction. It will contribute to a greater use of waste in construction, and therefore, meet the concept of sustainable development with the rational use of industrial waste of ornamental stones, noting the operational aspects, economic and environmentally correct, so as to provide lower costs and greater administrative control of this environmental liability.

\section{References}

[1] Abirochas Rochas Ornamentais no Século XXI: Bases para uma Politica de Desenvolvimento Sustentado das Exportações Brasileiras. Rio de Janeiro. CETEM/ABIROCHAS, 2001. $160 \mathrm{p}$.
[2] Anuário Mineral Brasileiro (2003/2004). DNPN/MM, Brasília.

[3] Associação Brasileira de Normas Técnicas. (1984). NBR 6459: Solos Determinação do Limite de Liquidez, Rio de Janeiro, 6p.

[4] Associação Brasileira de Normas Técnicas. (1984). NBR 7180: Solos Determinação do Limite de Plasticidade, Rio de Janeiro, 3p.

[5] Associação Brasileira de Normas Técnicas. (1984) NBR 7181: Solos Análise granulométrica.

[6] Associação Brasileira da Cerâmica. Site: http: /www.abceram.org.br

[7] Bustamante, G. M. - Bressiani, J. C.: A Ind. Cerâmica Brasileira. In: Cerâmica Industrial, 5(3)Maio/Junho, Cidade Universitária. São Paulo - SP, Brasil, 2000.

[8] Peyneau, G. O. R. - Pereira, G. S.: Tratamento dos Resíduos Provenientes das Serragens de Granito Através da Implantação do Filtro-Prensa. In: XXIV ENEGEP Florianópolis, SC, Brasil, 03 a 05 de Nov., 2004.

[9] Silva, J. B. - Hotza, D. - Segadães, A. M. - Acchar, W.: Incorporação de lama de mármore e granito em massas argilosas. Cerâmica, oct. /Dec. 2005. vol. 51, no. 320, p. 325-330. ISSN 0366-6913.

[10] Silva, S. A. C.: Caracterização do Resíduo da Serragem de Blocos de Granito Estudo do Potencial de Aplicação na Fabricação de Argamassas de Assentamento e de Tijolos de Solo-Cimento. Dissertação de Mestrado em Engenharia Ambiental, Universidade Federal do Espírito Santo, Vitória, ES. 1998.

[11] Souza, J. C. de.: Cadeia Produtiva do Setor de Rochas Ornamentais. In: Anais $V^{\circ}$ Simpósio de Rochas Ornamentais do Nordeste, 13 a 15 de Nov., Recife, 2005, p.193-203.

[12] Sumário Mineral (2004). DNPN/MME, Brasília.

\section{Díszkőipari por felhasználása kerámiaipari nyersanyagként}

Pernambuco Suape-i régiójában havonta mintegy $120 \mathrm{~m}^{3}$ fûrészelési iszap keletkezik. A fúrésziszap egy sưrūn folyó massza, amely a kôtömbök szétfúrészelésekor és lapokra vágásakor keletkezik, és acélszemcséket, mészhidrátot, vizet és kôport (a díszítôkô tömegének mintegy 40\%-át) tartalmaz. A vastartalom nem veszélyezteti a vörös agyag kerámiák mechanikai tulajdonságait. A kôvágási és csiszolási hulladék nagyobb mennyiségben tartalmaz a csiszolóporból származó finom homokszemcséket. A kôvágási és csiszolási hulladékban jelen lévó méretfrakciókat az agyag osztályozási görbéje is mutatja. Az ilyen hulladék hozzákeverhetô a kerámiatestek formázásához használt agyaghoz. A kôpor minták nem mutatnak plasztikus és folyási tulajdonságokat. A kerámiai alapanyag szükséges plaszticitása, kedvezô megmunkálhatósága egy erôsen plasztikus sötét agyag felhasználásával biztosítható. A hulladék anyagok ésszerú felhasználása csökkenti a környezet hulladékokkal való terhelését. 